\section{CHX Stabilizes the Resin/demineralized Dentin Interface}

\author{
Ana Rosa Costa@1, Lucas Zago Naves@2, Franklin Garcia-Godoy@3, \\ Fernanda Midori Tsuzuki[1, Américo Bortolazzo Correr(D), Lourenço \\ Correr-Sobrinho[1, Regina Maria Puppin-Rontani[4.
}

\begin{abstract}
The aim of this study was to evaluate the effect of $2 \%$ chlorhexidine digluconate $(\mathrm{CHX})$ on microtensile bond strength $(\mu \mathrm{TBS})$ between an adhesive system and under 3 dentin conditions. For that, this study evaluated the adhesive interface at initial, after 6 months and 1 year of storage. Forty-eight human third molars were prepared and randomly divided into 3 groups, according to dentin substrates: sound dentin $(\mathrm{Sd})$, caries-infected dentin $(\mathrm{Ci})$ and caries-affected dentin ( $\mathrm{Ca}$ ). The groups were subdivided into two according to the dentin pre-treatment: application of $2 \% \mathrm{CHX}$ or without pre-treatment (control). The dentin surfaces were etched with 35\% phosphoric acid gel and bonded with Adper Single Bond 2 (3M ESPE) adhesive system according to manufacturer's instructions. Subsequently, the specimens were stored in deionized water at $37^{\circ} \mathrm{C}$ for $24 \mathrm{~h}, 6$ months and 1 year. Two additional teeth were used to analyze the bonding interfaces by SEM. Data was submitted to three-way ANOVA in a split plot design and Tukey's test $(\alpha=0.05)$. The results showed that $\mathrm{Ci}$ decreased $\mu$ TBS values when compared to $\mathrm{Ca}$ and $\mathrm{Sd}$, regardless storages time or treatment. Stored samples for 6 months and 1 year decreased the $\mu$ TBS for the control group, but no difference was found between storages time for the $\mathrm{CHX}$ group. As a conclusion, the $2 \% \mathrm{CHX}$ application after etching showed improved dentin bond strength in the storage time, regardless of the substrates evaluated.
\end{abstract}

\begin{abstract}
1 Department of Restorative Dentistry, Dental Materials Division, Piracicaba Dental School, UNICAMP, State University of Campinas, Piracicaba, SP, Brazil

2 Department of Restorative Dentistry and Biomaterials, University Medical Center Groningen, The University of Groningen, Center for Dentistry and Oral Hygiene, Groningen, The Netherlands

${ }^{3}$ Department of Bioscience Research, University of Tennessee Health Science Center, Memphis, TN, USA

${ }^{4}$ Department of Health Sciences, Orthodontics and Pediatric Dentistry, Pediatric Division, Piracicaba Dental School, UNICAMP, State University of Campinas, Piracicaba, SP, Brazil
\end{abstract}

Correspondence: Ana Rosa Costa, Avenida Limeira, 901, 13414-903 Piracicaba, SP, Brasil. Tel: +55-192106-5345 e-mail: anarosacosta_1@hotmail.com

Key Words: heat, mechanical properties, dental materials, resin composites

\title{
Introduction
}

The minimally invasive technique is a clinical procedure proposed with a theoretical basis of cavity preparation that aims to remove infected and highly disorganized dentin, preserving the dentin affected by caries, which has less bacterial load and remineralization capacity $(1,2)$. Such selective caries excavation should prevent lesion progression, while maintaining the strength and stability of the remaining tooth structure in order to guarantee long-term mechanical resistance to intra-oral forces (1).

One of the concerns of the partial caries removal technique involves the remaining bacterial residues on the cavity walls, which may adversely affect the success of restorative treatments by causing pulp irritation, post-operative susceptibility, and recurrent caries $(3,4)$. Caries affected $(\mathrm{Ca})$ dentin is highly porous with obstructed dentinal tubules due to mineral crystals deposits. After removing the infected dentin, Ca may have remaining microorganisms. Cariogenic bacteria under the sealed restoration could multiply through dentinal tubules and cause secondary caries (5). So, prior to restoring, caries affected dentin needs to be disinfected by using different cavity disinfectants (6). Therefore, chemical agents to prevent carious progression or recurrent caries in dentin can be applied. Chlorhexidine (CHX) consists as a well-known disinfectant/antimicrobial agent and has been examined as a therapeutic primer for the preservation of hybrid layers in human dentin (7). In addition, it also preserves the bond strength of the dentin composite by acting as a matrix metalloproteinase (MMP) inhibitor (8-10).

Research studies that reported bond strength of resin adhesives to dentin from sound extracted teeth alone cannot be blindly extrapolated to clinically relevant $\mathrm{Ca}$ (11). Furthermore, high bond strength values measured immediately do not correlate with bonding longevity (12). Keeping this in mind, 
excellent effectiveness of immediate bond strength does not mean short- and long-term dentin bonding, longevity and stability of bonding interface to dentin (13).

In this context and considering that many questions remain regarding bonding to this type of substrate over longer periods, the current study aimed to compare bond strength of immediate, shortand long-term on altered dentin substrate, treated or not with $2 \%$ chlorhexidine digluconate (CHX). The null hypothesis tested was that $2 \% \mathrm{CHX}$ did not influence on bond strength, regardless of aging period or dentin substrate condition.

\section{Material and Methods}

The Research Ethic Committee (registration number 0412010) approved this study. Forty-eight freshly extracted and non-carious third molars were collected and stored in $0.1 \%$ thymol for 1 month and then stored in distilled water at $4^{\circ} \mathrm{C}$ until use. The occlusal enamel was sectioned perpendicular to the tooth long axis with a water-cooled diamond disc (EXTEC Corporation, Enfield, CT, USA) in a low speed saw machine (Isomet 1000, Buehler, Lake Bluff, IL, USA) to expose the subjacent dentin. Dentin was wet ground flat with 180 - and 600-grit silicon

\section{Artificial caries development}

Thirty-two molars were fixed with orthodontic wire on the lids of glass vials containing $40 \mathrm{~mL}$ of sterile distilled water and immediately sterilized by gamma irradiation (GC-220E, MDS Nordion, Ottawa, Canada) during $32 \mathrm{~h}$, at $27^{\circ} \mathrm{C}$, with a total dose of 14.5 (14). Specimens were then transferred to another sterile glass vial containing $40 \mathrm{~mL}$ of sterile brain-heart infusion (BHI) broth (\#21152, Becton Dickinson and Company, Sparks, MD, USA) supplemented with yeast extract (Himedia Laboratories, PVT Ltd., Mumbai, India), 0.5\% glucose (Synth; LabSynth, São Paulo, SP, Brazil), 1\% sucrose (Synth; LabSynth) and 2\% S. mutans (UA159) for development of the artificial carious lesions. The concentration of this bacterial suspension was determined by measuring absorption at $660 \mathrm{~nm}$ (A660). In order to adjust the number of viable bacteria to A660, the number of colony-forming units per milliliter of bacterial suspension (cfu/mL) was determined with the use of standard spreading techniques at carious optical densities. Inoculation occurred only in the first day of the experiment, but the media was renewed every $48 \mathrm{~h}$ during 14 days (15).

\section{Differentiation method: caries-infected and caries-affected dentin}

Caries-infected and caries-affected dentin was maintained or partially removed, respectively, after color identification using Caries Detector solution (Kuraray, Med. Inc, Okayama, Japan) associated to inspection criterion using dental explorers and visual examination, according to Momoi et al. (16) guideline for caries removal. The respective caries-removing endpoints for the experimental groups were: Caries-infected dentin (Ci) - soft deeply pigmented dentin was maintained. Caries-affected dentin (Ca) - soft-pigmented carious tissue was partially removed until hard and slightly pigmented dentin remained. The caries-affected dentin was removed using a \# 8 round carbide bur (KG Sorensen, Barueri, $\mathrm{SP}$, Brazil) mounted on a slow-speed handpiece.

\section{Microtensile specimens and bond testing}

Forty-eight sound teeth were randomly divided into three groups (16 specimens), according to the dental substrate: sound dentin $(\mathrm{Sd})$, caries-infected dentin $(\mathrm{Ci})$, and caries-affected dentin (Ca). Then, subdivided into two groups $(n=8)$ according to the surface treatment (2\% CHX application), or no treatment (control). The specimen preparation protocols were as follows:

No treatment groups (Control): after conditioning with 35\% phosphoric acid for $15 \mathrm{sec}$ (Scotch Bond Etchant, 3M ESPE, St. Paul, MN, USA), dentin was washed for $30 \mathrm{sec}$ and the excess water was removed with tissue paper. After, the dentin was rehydrated with deionized water, using a microbrush for $60 \mathrm{sec}$ and water excess removed with tissue paper. Thereafter, the Adper Single Bond 2 (3M ESPE, St. Paul, MN, USA) adhesive system was applied according to the manufacturer's recommendations.

Treated groups (2\% CHX application): after conditioning with 35\% phosphoric acid for $15 \mathrm{sec}$ (Scotch Bond Etchant, 3M ESPE, St. Paul, MN, USA), dentin was washed for $30 \mathrm{sec}$ and the water excess was removed with tissue paper. After, the dentin was rehydrated with $2 \%$ chlorhexidine digluconate (PRODERMA, Piracicaba, SP, Brazil), using a microbrush for $60 \mathrm{sec}$ and the water excess was removed with tissue paper. Thereafter, the Adper Single Bond 2 (3M ESPE, St. Paul, MN, USA) adhesive system was applied according to the manufacturer's recommendations.

Then, for all groups, surfaces were coupled with resin composite (Filtek Z350, 3M-ESPE), applied 
in 2-mm-thick increments light cured for 20s, using a quartz-tungsten-halogen light-curing unit at 700 $\mathrm{mW} / \mathrm{cm}^{2}$ (XL 2500, 3M-ESPE, St. Paul, MN, USA). The output power was checked with digital radiometer Hilux Light Meter (First Medica, Greensboro NC, USA). After restoration, the teeth were stored in distilled water at $37^{\circ} \mathrm{C}$ for $24 \mathrm{~h}$. Each specimen was sectioned perpendicularly to the bonding interface, into beams of approximately $1 \mathrm{~mm}^{2}$ area using a water-cooled diamond blade (EXTEC Corporation, Enfield, CT, USA) in a low-speed saw machine (Isomet 1000, Buehler Ltd., Lake Bluff, IL, USA). The cross-sectional area of the bond interface of each beam was measured using a digital caliper (Mitutoyo Corporation, Tokyo, Japan). Bond strength values were calculated and the data supplied in MPa. Beams at specimen peripheries were discarded.

Each beam was fixed to the grips of a microtensile device using a cyanoacrylate adhesive (Zapit; Dental Ventures of America Inc., Corona, CA, USA) and the test was conducted in a testing machine (EZ Test; EZS, Shimadzu, Tokyo, Japan) at a crosshead speed of $1.0 \mathrm{~mm} / \mathrm{min}$ until failure. The beams unable to be tested due to debonding on the pre-test were discarded and were not accounted for in the statistical analysis.

Microtensile bond-strength data were submitted to split-plot three-way ANOVA after observing the normal distribution of data and homoscedasticity of the variances, followed by Tukey's post hoc test (SAS Institute Inc., Cary, NC, USA, version 9.3) ( $p<0.05)$. The factors considered were: dentin substrate, pretreatment with $\mathrm{CHX}$ and the storage time. It was considered as factorial scheme the dentin substrate and pretreatment as parcel, and the storage time and the interactions between the factors as sub-parcels. Each tooth was considered the experimental unit while the beams were categorized as repetitions. None of beams debunked during bond strength testing.

\section{Failure mode analysis}

The failure mode was analyzed using a SEM (LEO 435 VP; LEO Electron Microscopy Ltd., Cambridge, UK) at $100 x$ to $3000 x$ magnification. The failure was classified according to the remaining structure predominant on its surfaces: adhesive (Mode 1); cohesive within dentin (Mode 2); cohesive within the composite (Mode 3); and mixed, involving bonding agent, composite and/or tooth structure (Mode 4). The results of failure mode classification were submitted to Fisher's Exact Test ( $R$, version 2.14.0, The R Foundation for Statistical Computing) $(p<0.05)$.

\section{Analysis of bonding interface}

Two additional restored teeth $(n=2)$ were vertically sectioned in $2 \mathrm{~mm}$ slices (about 8 slices per group), were then embedded in epoxy resin (Buehler, Lake Bluff, IL, USA). After each storage time, the slices were wet-polished using 600, 1200 and 2000-grit SiC papers (Norton SA, São Paulo, Brazil) and with decreasingly fine diamond compounds ( 3 um, 1um, 1/2 um, 1/4 um - Metadi II, Buehler, Lake Bluff, IL, USA). After each polishing step, the specimens were ultrasonically washed for $10 \mathrm{~min}$, demineralized with liquid $50 \% \mathrm{H}_{3} \mathrm{PO}_{4}$ for 5 seconds, rinsed in distilled water, deproteinized with $2.5 \% \mathrm{NaOCl}$ during 10 $\min$. The specimens were fixed in $2.5 \%$ glutaraldehyde in $0.1 \mathrm{M}$ cacodylate buffered solution titrated to $\mathrm{pH} 7.2$ for 72 hours and then rinsed several times with $0.1 \mathrm{M}$ sodium cacodylate buffered solution. They were dehydrated in ascending concentrations of ethanol $(50 \%, 60 \%, 70 \%, 80 \%$, and $90 \%)$ for 2 hours in each solution and in 100\% ethanol for $24 \mathrm{~h}$. The final chemical drying was conducted by immersion in hexamethyldisilazane for $10 \mathrm{~min}$ on filter paper inside a covered glass vial and air-drying at room temperature.

The specimens were gold coated with sputter coater under high-vacuum ambient (MED 010, Balzers Union, Aktiengeselischaft, Furstentun, Liechtenstein) for 180 seconds at $40 \mathrm{~mA}$ and examined using scanning electron microscopy (SEM; LEO 435 VP, Cambridge, England), operated at $20 \mathrm{KV}$ under magnification of 1000-5000x, by the same operator. The cross-section profiles were examined, focusing on the depth of etching, micromechanical entanglement, integrity, homogeneity and continuity along the bonded interface. The most representative images were selected.

\section{Results}

\section{Bond Strength}

Results for the $\mu$ TBS are shown in Table 1. Results of split-plot three-way ANOVA showed a significant difference for 'Substrate' $(p<0.0001)$ and 'Storage Time' $(p<0.0001)$ factors, but not for 'Treatment' $(p=0.2588)$. There was significant interaction between 'Treatment $x$ Storage Time' $(p=0.0246)$. 'Substrate $x$ Treatment' $(p=0.2506)$, 'Substrate $x$ Storage Time' $(p=0.7544)$ did not show significant interactions between factors. The triple interaction between factors was not significant $(p=0.9998)$. 
Overall, the comparison of $\mu$ TBS means (in MPa) for sound dentin (40.6) and caries-affected dentin (35.0) groups were significantly higher than caries-infected dentin (27.5), regardless storage time or treatment $(p<0.0001)$. The use of CHX did not show a significant difference in the $\mu$ TBS when compared to the control group ( $\mathrm{p}=0.2586$ ). For the control group, the $\mu \mathrm{TBS}$ (in MPa) after 24 hours (39.3) was significantly higher than storage for 6 months (30.7) and 1-year (29.5), regardless of substrate conditions. However, in the CHX group, no difference was found in $\mu$ TBS values (MPa) between the storage days $(p=0.0246)$.

Table 1. Means (SD) of $\mu \mathrm{TBS}$ (MPa) of dentin substrate exposed to cariogenic challenge.

\begin{tabular}{|c|c|c|c|c|c|c|c|c|}
\hline \multirow{3}{*}{ Substrate } & \multicolumn{3}{|c|}{ Control - Ct } & \multicolumn{3}{|c|}{$\mathrm{CHX}$} & \multirow{3}{*}{ Substrate } & \multirow{3}{*}{ Treatment } \\
\hline & \multicolumn{3}{|c|}{ Storage Time } & \multicolumn{3}{|c|}{ Storage Time } & & \\
\hline & 24 hours & 6 months & 1 year & 24 hours & 6 months & 1 year & & \\
\hline (Sd) Sound dentin & $47.1(9.5)$ & $38.8(7.7)$ & $37.7(8.1)$ & $41.4(5.0)$ & $39.9(8.8)$ & $38.6(7.7)$ & $\mathrm{Sd}(40.6)^{\mathrm{a}}$ & \multirow{4}{*}{$\begin{array}{c}\mathrm{Ct}(33.2)^{*} \\
\mathrm{CHX}(35.6) \\
*\end{array}$} \\
\hline $\begin{array}{l}\text { (Ca) Caries- } \\
\text { affected dentin }\end{array}$ & $\begin{array}{c}36.3(9.2) \\
\mathrm{Aa}\end{array}$ & $\begin{array}{c}29.6(9.1) \\
\mathrm{Ba}\end{array}$ & $\begin{array}{c}28.1(9.6) \\
\mathrm{Ba}\end{array}$ & $\begin{array}{c}39.2(10.5) \\
\mathrm{Aa}\end{array}$ & $\begin{array}{c}40.0(14.6) \\
\mathrm{Aa}\end{array}$ & $\begin{array}{c}36.8(11.4) \\
\mathrm{Aa}\end{array}$ & Ca (35.0) a & \\
\hline \multirow[t]{2}{*}{$\begin{array}{l}\text { (Ci) Caries- } \\
\text { infected dentin }\end{array}$} & $\begin{array}{c}34.4(13.8) \\
\mathrm{Ab}\end{array}$ & $\begin{array}{c}23.7(7.5) \\
\mathrm{Bb}\end{array}$ & $\begin{array}{c}22.7(5.2) \\
\mathrm{Bb}\end{array}$ & $\begin{array}{c}31.3(7.1) \\
\mathrm{Ab}\end{array}$ & $\begin{array}{c}27.6(8.6) \\
A b\end{array}$ & $\begin{array}{c}25.7(9.0) \\
A b\end{array}$ & \multirow[t]{2}{*}{$\mathrm{Ci}(27.5)^{b}$} & \\
\hline & (39.3) A & $(30.7)^{B}$ & $(29.5)^{B}$ & $(37.3)^{A}$ & $(35.8)^{A}$ & $(33.7)^{\mathrm{A}}$ & & \\
\hline
\end{tabular}

Means followed by different small letters in column and capital letters in row are significantly different $(p \leq 0.05)$. ${ }^{*}$ Means no difference between Control Group ( $\mathrm{Ct}$ ) and Chlorhexidine treated groups (CHX) ( $p=0.2586)$.

\section{Failure mode}

Failure mode results are shown in Table 2. Overall, the predominance of the mixed and adhesive failures was detected for all groups. Otherwise, cohesive failures in dentin decreased when chlorhexidine was applied. The occurrence of cohesive failures in composite was more evident in stored samples. The Fisher's Exact Test of the failure modes within each substrate condition showed a significant association between 'substrate condition' and 'storage time' relative to bond strength within each dentin treatment (using or not chlorhexidine): Control Group: $p=0.001163$ for Sound Dentin, $p=0.001118$ for Infecteddentin, $p=0.01009$ for Affected-dentin; CHX2\% Group: $p=0.009804$ for sound dentin, $p=0.02227$ for infected dentin, $p=0.004257$ for affected dentin.

Table 2. Distribution of failure mode after 24 hours, 6 months and 12 months in groups treated with water-wet bonding (Control group) or with $\mathrm{CHX} 2 \%$.

\begin{tabular}{|c|c|c|c|c|c|c|c|c|c|c|c|c|}
\hline \multirow{2}{*}{ Groups } & \multicolumn{3}{|c|}{ Adhesive (\%) } & \multicolumn{3}{|c|}{ Mixed (\%) } & \multicolumn{3}{|c|}{ CC (\%) } & \multicolumn{3}{|c|}{ CD (\%) } \\
\hline & $24 \mathrm{~h}$ & $6 \mathrm{~m}$ & $12 \mathrm{~m}$ & $24 h$ & $6 m$ & $12 \mathrm{~m}$ & $24 \mathrm{~h}$ & $6 m$ & $12 \mathrm{~m}$ & $24 \mathrm{~h}$ & $6 m$ & $12 m$ \\
\hline WWB-Sd & 35.7 & 25.5 & 55.5 & 50.0 & 42.5 & 17.8 & 2.40 & 25.5 & 15.5 & 11.9 & 6.4 & 11.1 \\
\hline WWB-Ca & 37.8 & 41.2 & 29.0 & 32.4 & 23.5 & 38.7 & 5.4 & 14.7 & 9.7 & 24.3 & 20.6 & 22.5 \\
\hline WWB-Ci & 26.8 & 40.5 & 32.4 & 48.8 & 27.0 & 45.9 & 2.40 & 10.8 & 5.4 & 21.9 & 21.6 & 16.2 \\
\hline $\mathrm{CHX}-\mathrm{Sd}$ & 28.9 & 43.1 & 22.9 & 47.4 & 23.5 & 37.5 & 15.8 & 29.4 & 33.3 & 7.9 & 3.9 & 6.2 \\
\hline $\mathrm{CHX}-\mathrm{Ca}$ & 66.7 & 33.3 & 65.8 & 28.6 & 51.3 & 26.3 & 4.7 & 12.8 & 7.9 & 0.0 & 2.5 & 0.0 \\
\hline $\mathrm{CHX}-\mathrm{Ci}$ & 50.0 & 40.5 & 56.4 & 43.2 & 47.6 & 35.9 & 0.0 & 11.9 & 5.1 & 6.8 & 0.0 & 2.5 \\
\hline
\end{tabular}

Failure mode: CC - cohesive failure in composite; CD - cohesive failure in dentin. Groups: WWB-Sd - water-wet bonding to sound dentin; $\mathrm{CHX}-\mathrm{Sd}$ - water-wet bonding with $2 \%$ chlorhexidine to sound dentin; WWB-Ca - water-wet bonding to caries-affected dentin; CHX-Ca water-wet bonding with $2 \%$ chlorhexidine to caries-affected dentin; WWB-Ci - water-wet bonding to caries-infected dentin; $\mathrm{CHX}-\mathrm{Ci}$ - waterwet bonding with $2 \%$ chlorhexidine to caries-infected dentin. $24 \mathrm{~h}-24$ hours; $6 \mathrm{~m}-6$ months; $12 \mathrm{~m}-12$ months. WWB-Sd: $p=0.001163$; WWB-Ca: $p=0.01009$; WWB-Ci: $p=0.001118 ; \mathrm{CHX}-\mathrm{Sd}: \mathrm{p}=0.009804 ; \mathrm{CHX}-\mathrm{Ca}: \mathrm{p}=0.004257$; and, $\mathrm{CHX}-\mathrm{Ci}: \mathrm{p}=0.02227$. 


\section{SEM characterization - Hybrid layer}

The results of SEM characterization are presented and described in detail in Figures 1-3. It was observed that all dentin substrates showed degradation of the bonding interface over time. Regardless of substrate conditions, there was bonding interface degradation, although $\mathrm{Ci}$ showed the highest bonding interface degradation level. Sd and Ca showed similar aspects of interface degradation, except resin tags conformation.



Figure 1. Sound dentin. A: Ct 24 h- hybrid layer (hl) presenting a continuous and homogenous interface; $\mathrm{B}$ - Ct 6 months - hl presenting a continuous and homogenous interface; slightly extensions of micro tags branching off at angles from the main resin tags ( $\mathrm{rt}$ ) are visible; $\mathrm{C}-\mathrm{Ct} 1$ year - extensive and deep alterations suggesting a higher degree of degradation of dentinal substrate (pointer) and superficial resin tag penetration (arrow); D - CHX $24 \mathrm{~h}-\mathrm{hl}$ over $\mathrm{CHX}$ treated dentin presenting a continuous and homogenous interface; $\mathrm{E}-\mathrm{CHX} 6$ months - possible interface flaws seems to originate on bottom of hybrid layer (pointer); F - CHX 1 year - although some flaw and discontinuities are already detected (arrow), the hybridization seems preserved (pointer). c: composite; ad: adhesive; hl: hybrid layer; rt: resin tag; d: dentin.

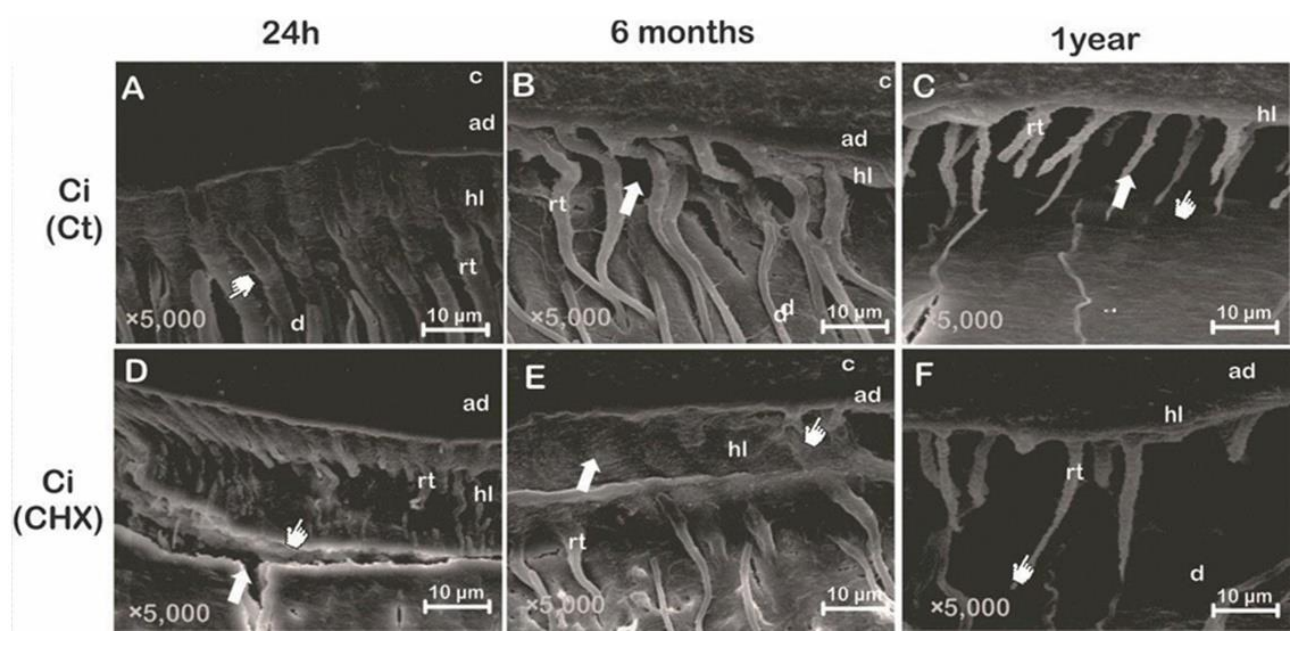

Figure 2. Caries-infected dentin. A: Ct $24 \mathrm{~h}$ - hybrid layer (hl) after water wet-bonding presenting abnormal thin resin tags (pointer); B - Ct 6 months - altered $\mathrm{hl}$ and degradation points (black areas arrow); C - Ct 1 year - extensive and deep alterations (pointer) suggesting a higher degree of degradation of hl; arrow showing thin and abnormal resin tag (rt) aspect; D - CHX $24 \mathrm{~h}$ - formation of polymeric tags over abnormal dentin tissue (pointer) and arrow showing some initial dentin flaw; $\mathrm{E}$ - CHX 6 months - the interface presents unusual aspect of hl (arrow) and initial flaw detected (pointer); F - CHX 1 year - abnormal resin tag (rt) aspect (pointer). c: composite; ad: adhesive; hl: hybrid layer; rt: resin tag; d: dentin. 


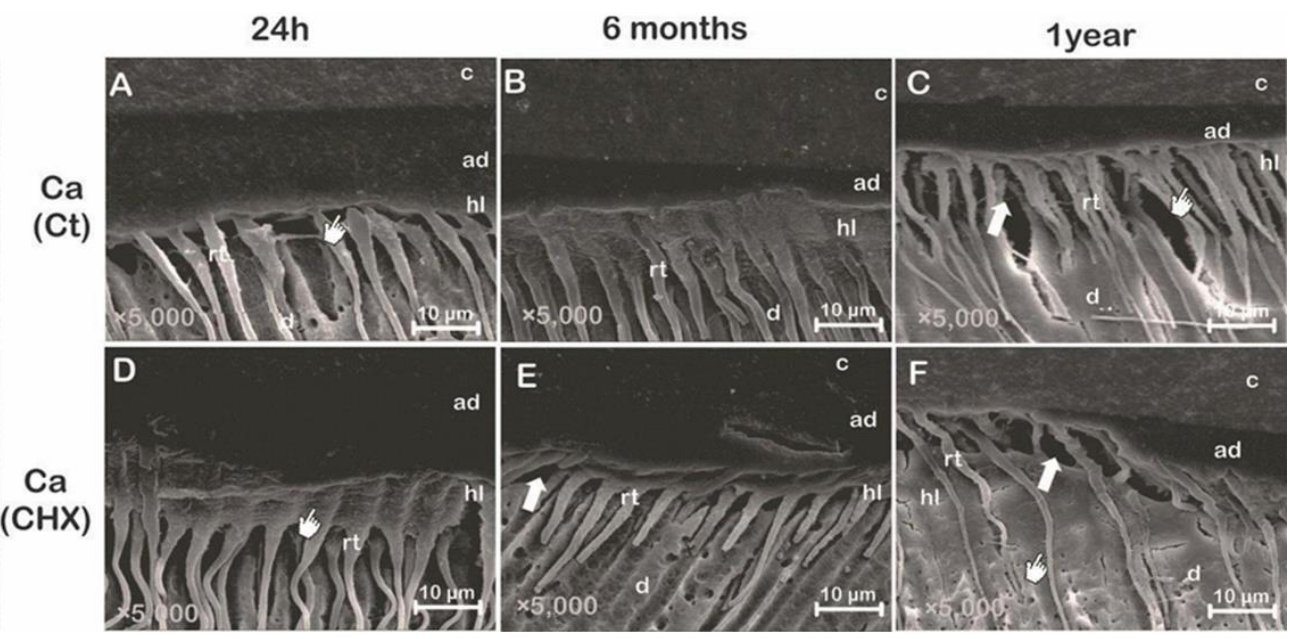

Figure 3. Caries-affected dentin. A: Ct $24 \mathrm{~h}$ - unusual aspect of hybrid layer ( $\mathrm{hl}$ ) presenting some polymeric tags with constriction (pointer); B - Ct 6 months - hl degradation; C - Ct 1 year - extensive alterations suggesting a higher degree of degradation of $\mathrm{hl}$ (arrow) and thin and abnormal resin tag aspect (pointer); D - CHX $24 \mathrm{~h}$ - pointer showing hybridization of intertubular dentin and unusual aspect of hl; E - CHX 6 months - the interface presents some disruptive failure at bottom of hl showing initial degradation of (arrow); F - CHX 1 year: debonding at the bottom of HL (arrow). Pointer is showing abnormal dentinal tissue aspect suggesting dentin degradation by microorganism activity during caries producing. c: composite; ad: adhesive; hl: hybrid layer; rt: resin tag; d: dentin.

\section{Discussion}

In the present study, an investigation to the long-term bonding performance of an adhesive system when used in combination with $\mathrm{CHX}$ was performed. The null hypothesis that $2 \% \mathrm{CHX}$ did not influence bond strength, irrespective of aging period or dentin substrate condition was rejected. According to our results, the dentin pretreatment with $\mathrm{CHX}$ before the application of the adhesive system influenced bond strength of all dentin substrate conditions over time.

CHX preserves the bond strength of the dentin composite by acting as an MMP inhibitor $(9,10)$. Results from the current study indicates the effectiveness of CHX as an MMP inhibitor or as an antimicrobial agent on bond durability and/or tissue integrity, it promoted a decrease in cohesive failures in dentin. These results corroborate with previous studies reporting that the use of $\mathrm{CHX}$ influenced the immediate bond strength and prevents, or at least decelerates the deterioration of resin-dentin bonds teeth $(17,18)$.

Clinicians frequently must deal with caries-affected and caries-infected dentin, and probably, sound dentin is not the most encountered substrate in clinical situations (19). The caries-infected dentin is a superficial necrotic zone of vastly demineralized substrate, with degenerated collagen fibrils that lost their cross-linking $(20,21)$. The bonding effectiveness to caries-infected dentin was in general lower than to 'sound' and 'caries-affected' dentin and the different caries-removing techniques resulted in different bonding-receptive dentin substrates, regardless storage time or treatment. This is because carious intertubular dentin exhibits a higher degree of porosity than sound intertubular dentin, due to the loss of mineral could reduce the activity of metalloproteinase and proteases involved in collagen degradation $(19,22)$. Some studies suggested that faster bonding degradation is closely related to increased collagenolytic activity in the caries-affected and caries-infected dentin when compared to sound dentin $(9,23)$.

Natural caries-affected dentin usually presents lower dentinal tubule permeability due the presence of mineral crystals blocking fully or partially tubule lumen. Pacheco et al. (19) showed that similar mineral content concerning $\mathrm{Ca}_{1} \mathrm{CO}_{3}$ and $\mathrm{PO}_{4}$ and organic content like $\mathrm{CH}$ bonds might be found also in vitro when $\mathrm{S}$ mutans biofilm provided dentin carious lesions compared with the natural ones. Although, this situation may result in less hydrolytic degradation of hybrid layer due to the drastic decrease in the water uptake, this tubule block can compromise the adhesive infiltration towards tubular- and inter-tubular dentin (10). This corroborates the finds of the SEM analysis. The formation of 
small polymeric tags over caries-infected dentin were sometimes detected; in addition, it was observed an unusual hybrid layer conformation thin and abnormal resin tags aspect and altered dentinal tissue in the characterization of the SEM was observed, regardless of treatment with CHX (Figures 2A-F). The imaging conditions mentioned above may be a possible explanation for the decrease in bond strength for the Ci group.

In the present study, CHX showed similar bond values in sound dentin and caries-affected dentin specimens stored when compared to caries-infected dentin. However, it is expected that there will be a challenge on bonding to caries-affected dentin since the dissolution of apatite crystals, the greater intrinsic water content, reduced calcium and degradation of unprotected collagen by bacterial and hostmediated enzymes may negatively impact the performance of the adhesives applied to this substrate $(5,11,24)$. Additionally, a more porous intertubular dentin may be found because of the partial demineralization $(5,24)$. Hydrogen bonding between resins and collagen may occur to the bond strength in sound dentin and perhaps dentin affected by caries if it has normal collagen. Possibly, an explanation for these two substrates to have similar values would be that the collagen fibrils Ca were not totally denatured unlike what happened with the denatured matrix of the dentin infected by caries.

The etch-and-rinse 2-step adhesive (Adper Single Bond 2, 3M ESPE, St. Paul, MN, USA) used contain functional monomers in its composition that can interact with the calcium ions left on the dentin surface, or even with the underlying dentin (25). It also contains hydrophilic copolymer of the polyalkenoic acid that is believed to form Ca-polyalkenoic acid-base complexes (25). Assuming that chelating interactions exist between the acidic monomer and mineralized dentin, a reduction in hydroxyapatite crystallite availability (due to caries demineralization) may have limited its bonding efficacy on caries-infected dentin and even in caries-affected dentin groups (11).

Acid etching prior to the use of conventional adhesive systems promotes deeper infiltration into the dentin. Therefore, CHX could probably infiltrate more easily through the dentinal tubules and interfere in the bonding procedure, preventing the formation of a uniform hybrid layer (25). This study results could be different if the adhesive used were the universal adhesive, since the reduced demineralization obtained with self-etching approaches maintains the availability of hydroxyapatite crystals within the hybrid layer for chemical bond between the functional monomers and calcium ions that contributes to the stability and durability of the adhesive interface. Universal adhesive systems have Methacryloyloxydecyl dihydrogen phosphate (MDP) in their composition, which enhances the chemical bond to hydroxyapatite (25).

To compare the long-term performance of the adhesive and the effects of CHX on the stability of the adhesive interface, 6 months and 1-year storage was proposed. In this study, no significant reduction in $\mu$ TBS of all dentin substrate conditions in aged samples ( 6 months and 1 year) was found, while in the absence of $\mathrm{CHX}$ treatment (control group), significant reductions were observed. Degradation of resin-demineralized dentin interface over time was observed in the current study, represented by some interface disruption and discontinuities in samples analyzed by SEM after 6 months and 1 year of water storage, as noted in Figures 2 and 3 . However, chlorhexidine digluconate minimized the reduction in resin-dentin bond strengths commonly observed after long-term water storage. Since the activation of MMPs can result in increased enzymatic activity over time and chlorhexidine digluconate could impair this deleterious effect $(9,10)$.

Our results confirm the findings that $\mathrm{CHX}$ can stabilize bond strength to dentin over time. Thus, the use of $\mathrm{CHX}$ is advantageous. Bond strength to dentin may differ based on caries removal techniques, bonding agents, types of materials used and these variations limit the results of this study. One limitation of the study is the in vitro design of the study, although the standardization has been guaranteed, it does not fully reflect the clinical conditions. Therefore, further studies are needed to validate the clinical significance of these findings.

Under the conditions of this in vitro study, it could be concluded that CHX stabilizes bond strength to dentin over time, regardless substrate conditions. In addition, time is the most important factor in the bond strength degradation when CHX was not applied. Finally, bonding with caries-infected dentin decreases the bond strength values, when compared to caries-affected and sound dentin, regardless storage time or treatment.

\section{Acknowledgements}

This study was supported by Fundação de Amparo à Pesquisa do Estado de São Paulo - FAPESP (Grant 2010/07829-2). Thanks to Dr. EW Kitajima, Dr FAO Tanaka, and RB Salaroli (Núcleo de Apoio à Pesquisa em Microscopia Eletrônica, NAPME/ESALQ/USP, Brazil) for SEM equipment support. The authors 
are indebted to Dra. Glaucia Maria Bovi Ambrosano (Department of Health Orthodontics and Pediatric Dentistry) for statistic analysis.

\section{Resumo}

0 objetivo deste estudo foi avaliar o efeito do digluconato de clorexidina 2\% (CHX) na resistência de união à microtração ( $\mu \mathrm{TBS}$ ) entre um sistema adesivo e sob 3 condições de dentina. Para tanto, este estudo avaliou a interface adesiva no início, após 6 meses e 1 ano de armazenamento. Quarenta e oito terceiros molares humanos foram preparados e divididos aleatoriamente em 3 grupos, de acordo com os substratos dentinários: dentina hígida (Dh), dentina infectada por cárie (Di) e dentina afetada por cárie (Da). Os grupos foram subdivididos em dois de acordo com o pré-tratamento: aplicação de CHX 2\% ou sem pré-tratamento (controle). As superfícies da dentina foram condicionadas com gel de ácido fosfórico a 35\%, em seguida, utilizou-se o sistema adesivo Adper Single Bond 2 (3M ESPE) de acordo com as instruções do fabricante. Posteriormente, os corpos-de-prova foram armazenados em água deionizada a $37^{\circ} \mathrm{C}$ por $24 \mathrm{~h}, 6$ meses e 1 ano. Dois dentes adicionais foram usados para analisar as interfaces de união no MEV. Os dados foram submetidos a ANOVA três fatores em esquema de parcela subdividida e ao teste de Tukey $(\alpha=0,05)$. Os resultados mostram que a Di diminuiu os valores de $\mu$ TBS quando comparado as Da e Dh, independente do tempo de armazenamento ou tratamento. Amostras armazenadas por 6 meses e 1 ano diminuíram a $\mu$ TBS para o grupo de controle, mas nenhuma diferença foi encontrada entre o tempo de armazenamento para o grupo CHX. A aplicação de $\mathrm{CHX} 2 \%$ após o condicionamento apresentou melhora na resistência de união à dentina no tempo de armazenamento, independente dos substratos avaliados.

\section{References}

1. Tyas MJ, Anusavice KJ, Frencken JE, Mount GJ. Minimal intervention dentistry--a review, FDI Commission Project 1-97. Int Dent J 2000;50:1-12.

2. x1Cardoso M, Coelho A, Lima R, Amaro I, Paula A, Marto CM, Sousa J, Spagnuolo G, Marques Ferreira M, Carrilho E. Efficacy and Patient's Acceptance of Alternative Methods for Caries Removal-a Systematic Review. J Clin Med 2020;23;9:3407.

3. Hoefler V, Nagaoka $H$, Miller CS. Long-term survival and vitality outcomes of permanent teeth following deep caries treatment with step-wise and partial-caries-removal: A Systematic Review. J Dent 2016;54:25-32.

4. Pedrotti $D$, Cavalheiro $C P$, Casagrande $L$, de Araújo FB, Pettorossi Imparato JC, de Oliveira Rocha $R$, Lenzi TL. Does selective carious tissue removal of soft dentin increase the restorative failure risk in primary teeth?: Systematic review and meta-analysis. J Am Dent Assoc 2019;150:582-590.

5. Yoshiyama M, Tay FR, Doi J, Nishitani Y, Yamada T, Itou K, et al. Bonding of self-etch and totaletch adhesives to carious dentin. J Dent Res 2002;81:556-560.

6. Al Deeb L, Bin-Shuwaish MS, Abrar E, Naseem M, Al-Hamdan RS, Maawadh AM, Al Deeb M, Almohareb T, Al Ahdal K, Vohra F, Abduljabbar T. Efficacy of chlorhexidine, Er Cr YSGG laser and photodynamic therapy on the adhesive bond integrity of caries affected dentin. An in-vitro study. Photodiagnosis Photodyn Ther 2020;31:101875.

7. Ruksakiet K, Hanák L, Farkas N, Hegyi P, Sadaeng W, Czumbel LM, Sang-Ngoen T, Garami A, Mikó A, Varga G, Lohinai Z. Antimicrobial Efficacy of Chlorhexidine and Sodium Hypochlorite in Root Canal Disinfection: A Systematic Review and Meta-analysis of Randomized Controlled Trials. J Endod 2020;46:32-41.

8. Gendron R, Grenier D, Sorsa T, Mayrand D. Inhibition of the activities of matrix metalloproteinases 2, 8, and 9 by chlorhexidine. Clin Diagn Lab Immunol 1999;6:437-439.

9. Hebling J, Pashley DH, Tjaderhane L, Tay FR. Chlorhexidine arrests subclinical degradation of dentin hybrid layers in vivo. J Dent Res 2005;84:741-746.

10. Carrilho MR, Geraldeli S, Tay F, de Goes MF, Carvalho RM, Tjäderhane L, Reis AF, Hebling J, Mazzoni A, Breschi L, Pashley D. In vivo preservation of the hybrid layer by chlorhexidine. J Dent Res 2007;86:529-533.

11. Ekambaram M, Yiu CKY, Matinlinna JP. Bonding of resin adhesives to caries-affected dentin - $A$ systematic review, Inter J of Adhe and Adhes 2015;61:23-34.

12. De Munck J, Van Landuyt $K$, Peumans M, Poitevin A, Lambrechts $P$, Braem $M$, et al. A critical review of the durability of adhesion to tooth tissue: methods and results. J Dent Res 2005;84:118-132. 
13. Costa AR, Correr-Sobrinho L, Ambrosano GM, Sinhoretti MA, Borges GA, Platt JA, PuppinRontani R. Dentin Bond Strength of a Fluoride-Releasing Adhesive System Submitted to pH-Cycling. Braz Dent J 2014;25:472-478.

14. Carvalho FG, Fucio SB, Pascon FM, Kantovitz KR, Correr-Sobrinho L, Puppin-Rontani RM. Effect of gamma irradiation on fluoride release and antibacterial activity of resin dental materials. Braz Dent J 2009;20:122-126.

15. de Carvalho FG, de Fucio SB, Sinhoreti MA, Correr-Sobrinho L, Puppin-Rontani RM. Confocal laser scanning microscopic analysis of the depth of dentin caries-like lesions in primary and permanent teeth. Braz Dent J 2008;19:139-144.

16. Momoi $Y$, Hayashi M, Fujitani M, Fukushima $M$, Imazato $S$, Kubo $S$ et al. Clinical guidelines for treating caries in adults following a minimal intervention policy - Evidence and consensus-based report. Journal of Dentistry 2012;40:95-105.

17. de Castro FL, de Andrade MF, Duarte Junior SL, Vaz LG, Ahid FJ. Effect of $2 \%$ chlorhexidine on microtensile bond strength of composite to dentin. J Adhes Dent 2003;5:129-138.

18. Komori PC, Pashley DH, Tjaderhane L, Breschi L, Mazzoni A, de Goes MF, et al. Effect of $2 \%$ chlorhexidine digluconate on the bond strength to normal versus caries-affected dentin. Oper Dent 2009;34:157-165.

19. Pacheco LF, Banzi ECF, Rodrigues E, Soares LES, Pascon FM, Correr- Sobrinho LC, et al. Molecular and structural evaluation of dentin caries-like lesions produced by different artificial models. Braz Dent J 2013;24:238-244.

20. de Almeida Neves A, Coutinho E, Cardoso MV, Lambrechts $P$, Van Meerbeek B. Current concepts and techniques for caries excavation and adhesion to residual dentin. J Adhes Dent 2011; 13:7-22.

21. Costa AR, Garcia-Godoi F, Correr-Sobrinho L, Naves LN, Raposo LH, Carvalho FG, Sinhoretti MA, Puppin-Rontani R. Influence of Different Dent in Substrate (Caries-Affected, Caries-Infected, Sound) on Long-Term $\mu$ TBS. Braz Dent J 2017;28:1-8.

22. Joves GJ, Inoue G, Sadr A, Nikaido T, Tagami J. Nanoindentation hardness of intertubular dentin in sound, demineralized and natural caries-affected dentin. J Mech Behav Biomed Mater 2014;32:39-45.

23. Dayan D, Binderman I, Mechanic GL. A preliminary study of activation of collagenase in carious human dentin matrix. Arch Oral Biol 1983;28:185-187.

24. Isolan CP, Sarkis-Onofre R, Lima GS, Moraes RR. Bonding to Sound and Caries-Affected Dentin: A Systematic Review and Meta-Analysis. J Adhes Dent 2018;20:7-18.

25. Nakajima M, Hosaka K, Yamauti M, Foxton RM, Tagami J. Bonding durability of a self-etching primer system to normal and caries-affected dentin under hydrostatic pulpal pressure in vitro. Am J Dent 2006;19:147-150.

Received: 03/05/2021

Accepted: $24 / 09 / 2021$ 